\title{
Petrological evolution of the Eastern Ghats Belt- Current status and future directions
}

\author{
Indian Institute of Science Education \& Research, Kolkata; Email: somnath@iiserkol.ac.in
}

(Received : 24/03/2019; Revised accepted : 17/09/2019)

https://doi.org/10.18814/epiiugs/2020/020007

The present communication aims at an assessment of the current status on petrological evolution of the Eastern Ghats Belt in the context of its correlation with three supercontinents, namely Columbia, Rodinia and East Gondwana. Despite intensive research by different groups over the last three decades, various issues remain unresolved. Some major outstanding issues include, the nature of the basement for the Eastern Ghats rocks, isotopic and / or lithotectonic subdivisions of the belt, nature of the retrograde path of UHT metamorphism and timing of juxtaposition of the mobile belt with the adjacent cratons.

\section{Introduction}

The Eastern Ghats Belt along the east coast of India (Figure 1) has been the focus of intensive investigations by Indian as well as scientists from abroad because of various reasons mentioned below. First of all, it was clearly understood since the introduction of the concept of Supercontinents, Supercontinent Cycle and advancement in our perception of the history of the continents over the last 3 billion years (for example, Rogers, 1996, references therein), that the Eastern Ghats Belt (EGB) is the key missing link to the supercontinents of Rodinia and Gondwana. The supercontinent of Columbia was added later to the list (Zhao et al., 2004). Secondly, the EGB hosts one of the spectacular occurrences of ultrahigh temperature metamorphism

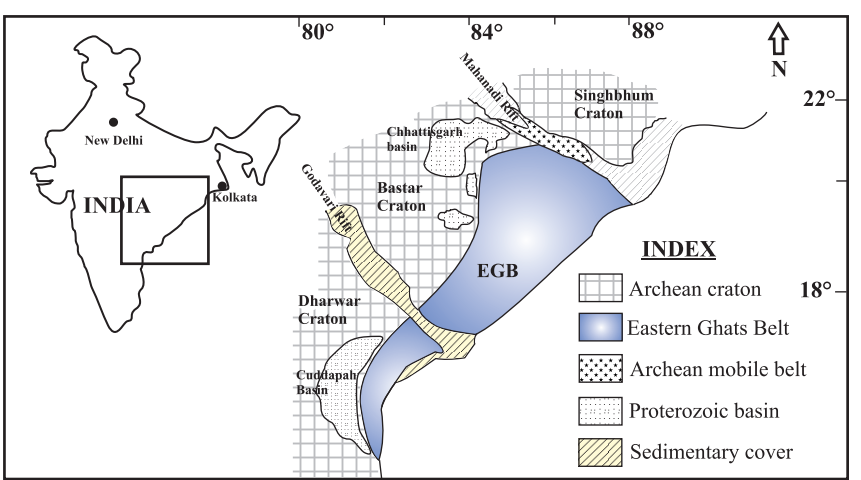

Figure 1. Eastern Ghats Belt in India. at mid- to lower crustal depths (Lal et al., 1987, Sengupta et al., 1990, Dasgupta, 1993; Bhowmik et al., 1995; Sengupta et al., 1999; Bose et al., 2000; reviewed in Harley, 2008, Kelsey, 2008). As a consequence, several geodynamic models were put forward to explain the reason of "anomalous" heat supply at the base of the crust. A related topic of intense discussion was the nature of the prograde and retrograde metamorphic P-T trajectory of evolution of the ultrahigh temperature granulites (reviewed in Dasgupta et al., 2017). Thirdly, the EGB borders three cratonic blocks in the Indian subcontinent (Dharwar, Bastar and Singhbhum), and, therefore, is expected to have played a role in suturing of the cratons. Naturally, the timing of amalgamation of the Proterozoic mobile belt with the cratons is of significance, and this issue is as yet unresolved.

Finally, although fairly accurate and detail geological maps were compiled, primarily by the Geological Survey of India (e.g. Ramakrishnan et al., 1998), isotopic investigations were initiated much later, notwithstanding important geochronological data generated on isolated occurrences (e.g. Grew and Manton, 1986: Paul, 1990; Kamineni and Rao,1988). Detailed isotopic mapping with Nd isotopes (Rickers et al., 2001) and geochronological studies using multiple isotope systematics (reviewed and referenced in Dasgupta et al., 2013, 2017) provided a complicated picture of evolution of different parts of the EGB identifying multiple isotopic provinces and domains with complex separate temporal and spatial evolution. Table 1 in Dasgupta et al. (2013) gives a compilation of the then available geochronologic data on the rocks of the EGB. Some of these issues remain unresolved as of today and will merit further integrated studies (discussed at the end of this communication). In this background, this communication will review some of the major advances in our understanding of the EGB (with special reference to petrological and isotopic issues) and some important outstanding issues. In the recent years, several tectonothermal models have been put forward to explain evolution of different parts of the EGB without general consensus. The purpose of this communication (an updated status report) is to stick to factual data as far as possible, to point out discordance in interpretation, and to flag outstanding science questions without attempting an evaluation of the results and speculative tectonothermal models. The reader is, therefore, left free to develop own interpretation in contentious issues.

\section{Geological background}

Paragneisses in the EGB include khondalite (garnet-sillimaniteperthite-plagioclase-quartz), calcsilicate granulites (scapolite- 
wollastonite-calcite-grandite garnet-plagioclase-clinopyroxene), leptynite (garnet-perthite-quartz-plagioclase) and high $\mathrm{Mg}-\mathrm{Al}$ granulites (sapphirine-spinelaluminous orthopyroxene-cordieritequartz / corundum, garnet- sillimanite). Two varieties of orthogneisses are exposed- mafic granulite (orthopyroxene-clinopyroxene-garnetplagioclase) and enderbite (quartz-plagioclase-orthopyroxene-garnetperthite) or charnockite (mineralogy same as enderbite, but perthite>> plagioclase). A layered mafic-ultramafic igneous complex occurs at Kondapalle, southern EGB, and massif-type anorthosites occur in the northern part. Alkaline rocks commonly occur in the northwestern part of the EGB, near the contact with the cratons.

A generalized geological map of the EGB is shown in Figure 2 (after Ramakrishnan et al., 1998). These authors divided the EGB into the following lithotectonic zones from west to east:

1. Western Charnockite Zone

2. Western Khondalite Zone

3. Central Migmatite Zone

4. Eastern Khondalite Zone.

A Transition Zone with alkaline intrusives is supposed to occur in the westernmost part at the contact with the Bastar craton. Two prominent NNE-SSW to NE-SW trending rifts- the Mahanadi rift on the north and the Godavari rift on the south- dissect the EGB. Several later workers have pointed out that the subdivisions are rather simplistic, as there are considerable overlaps in lithology across the zones, and are particularly not consistent with isotopic data generated later. The location of the Transition Zone is also problematic (Gupta et al., 2000). Chetty and Murthy (1994) identified several major shear zones or lineaments either traversing the EGB or along the mobile belt - craton contact. Some of these shear zones were taken to be terrane boundaries by Rickers et al. (2001) (see below).

Isotopic mapping, on the other hand, suggests that the EGB is an amalgamation of different terranes / provinces / domains, each of which has distinct tectonothermal history. Rickers et al. (2001)

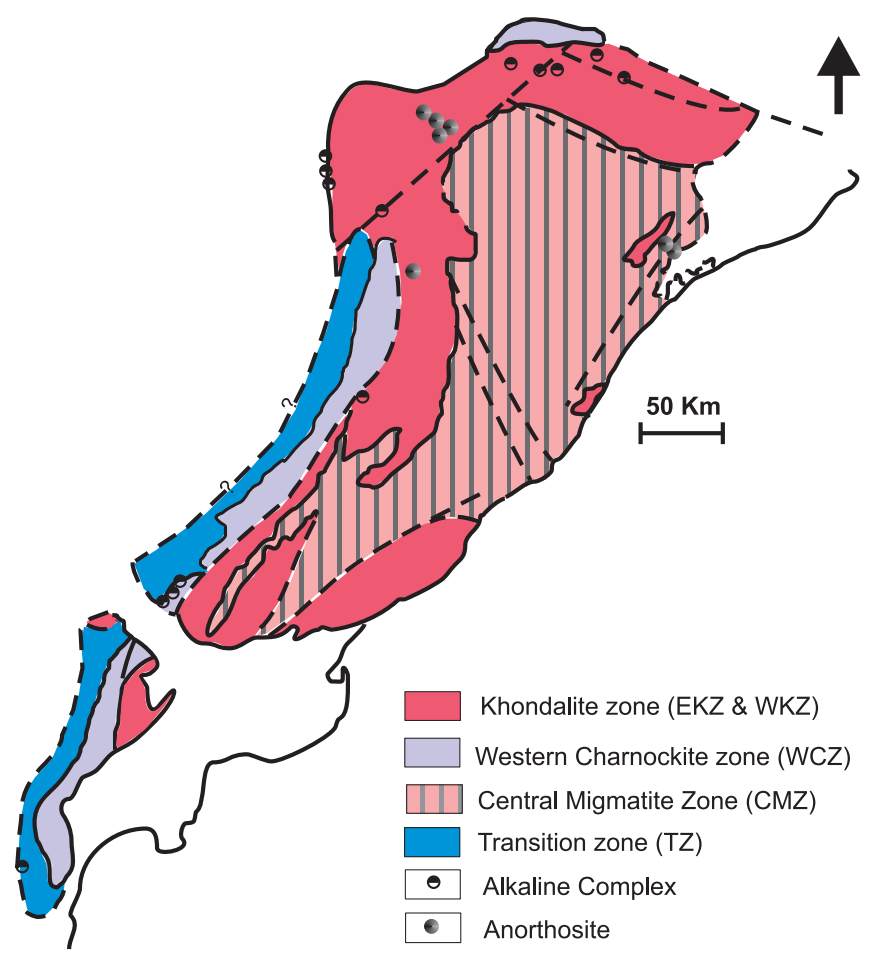

Figure 2. Geological map of EGB (Ramakrishnan et al., 1998) identified four such crustal domains based on $\mathrm{Nd}$ isotopic data, supported by Rb-Sr and $\mathrm{Pb}$ isotopic data (Figure 3). The WCZ of Ramakrishnan et al. (1998) was considered to be of two separate crustal domains (IA, south of Godavari Rift; IB, north of the rift) with domain 1B having Nd model ages between 3.9-2.9 Ga. Domain

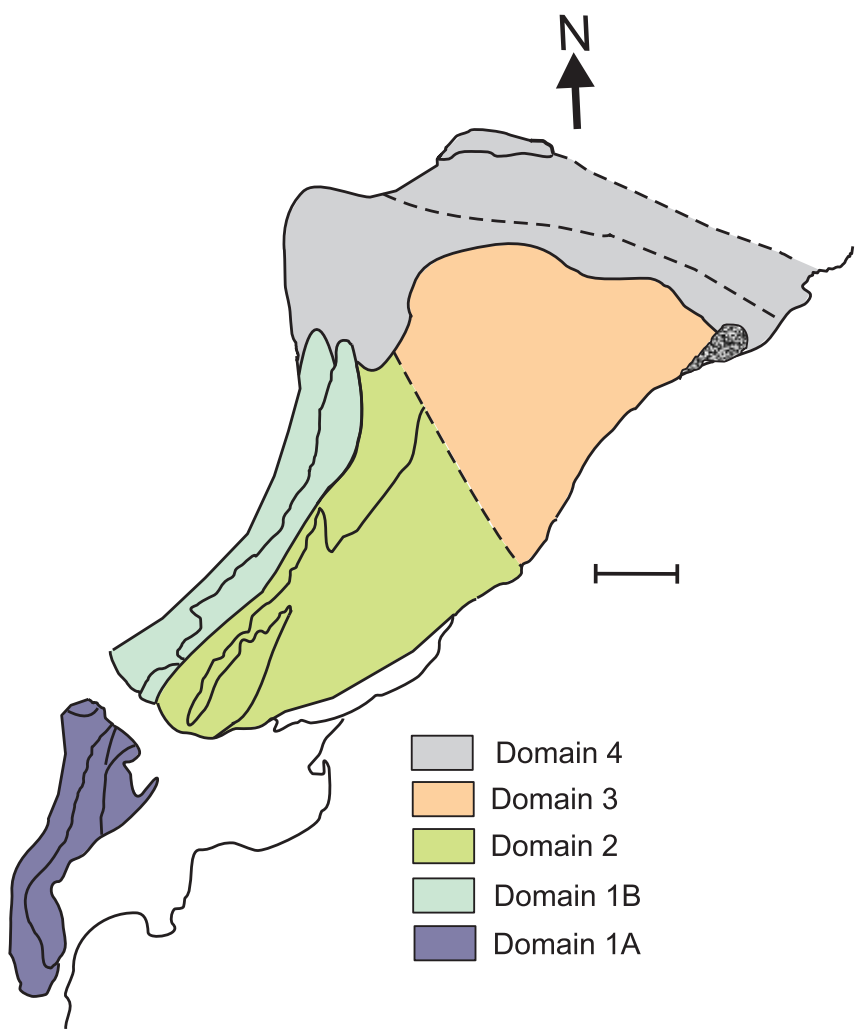

Figure 3. Isotopic domains in EGB (after Rickers et al., 2001)

$1 \mathrm{~A}$ was thought to have Proterozoic crustal materials. Rickers et al. (2001) identified three other isotopic domains north of the Godavari Rift. The domain near Chilka Lake (III) contained materials with model age of 1.8-2.2 Ga and intrusive anorthosites of $\sim 800-900 \mathrm{Ma}$ age according to different estimates. They correlated the northern and southern boundaries of the domain coinciding with the Mahanadi and Nagavalli Bamasdhara lineaments respectively. The domain II sandwiched between domain IA and domain III is isotopically heterogeneous. The Sileru shear zone marks the western boundary of domain II. The orthogneisses show gradual variations in Nd model ages from 3200 Ma near the Godavari Rift to 1800 Ma towards NE, while paragneisses have model ages of 2500-2100 Ma. There is hardly any consensus about the Angul domain (IV) (Nd model age 2.9-2.5 $\mathrm{Ga}$ ) and its relationship with the domain III (see discussion in Dasgupta et al., 2003, 2017).

Dobmeier \& Raith (2003) proposed that the EGB is an amalgamation of several crustal units (so-called provinces and domains), each having distinct geological histories of evolution. Accordingly, they identified four provinces (Eastern Ghats, Rengali, Jeypore and Krishna) (Fig.4). Within the Krishna Province, they identified one domain (the Ongole Domain), that was metamorphosed to granulite-facies condition. The Eastern Ghats Province (EGP) comprises the isotopic domains 2 and 3 of Rickers et al. (2001), while the Ongole Domain is the same as isotopic Domain 1A of these authors. The EGP was subdivided into different isotopic domains

Episodes Vol. 43, no. 1 


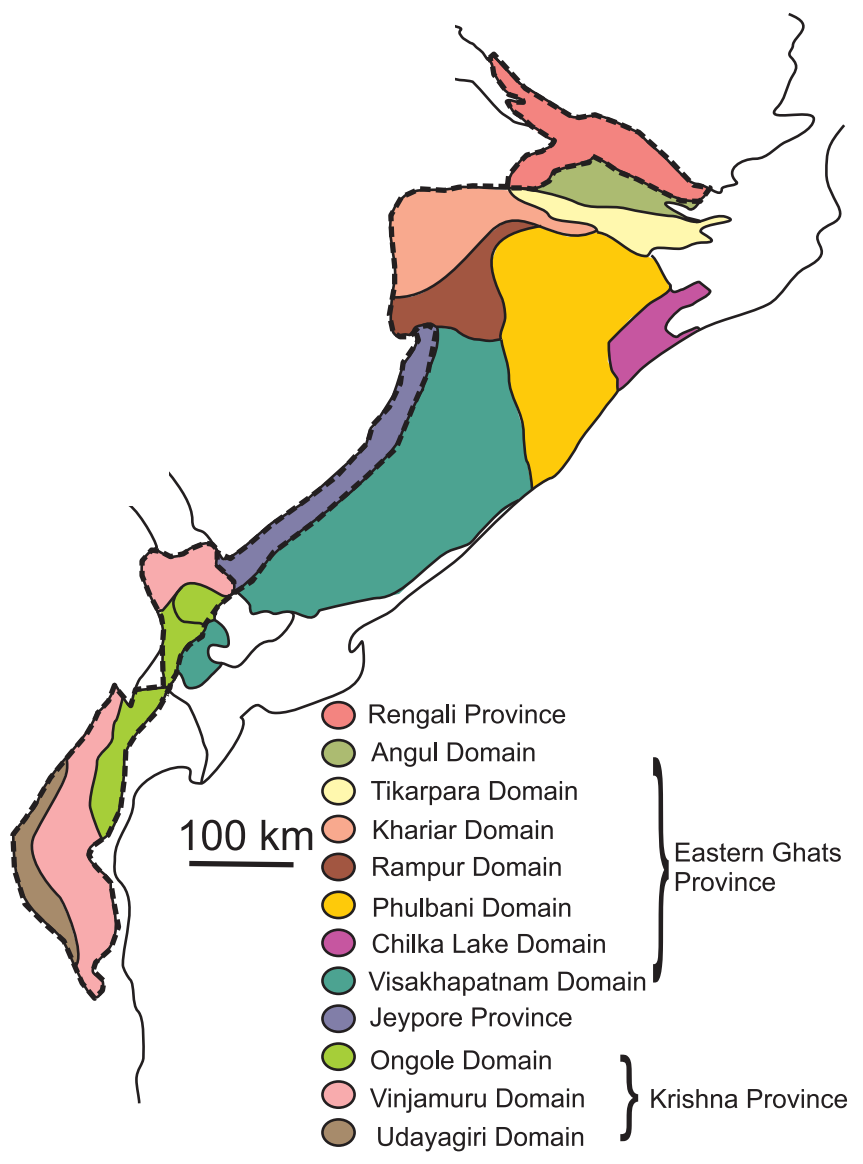

Figure 4: Different Provinces and Domains in EGB (after Dobmeier and Raith, 2003).

(Fig. 4), which do not necessarily coincide with the subdivisions proposed by Rickers et al.(2001). The Jeypore province is identical to isotopic domain I B of Rickers et al. (2001). The Rengali Province (Crowe et al., 2001; 2003; Dobmeier and Raith, 2003) is distinctly older, is in contact with the Singhbhum craton, and is separated from the Eastern Ghats Belt by a strip of Gondwana sediments, all of which make the geological relationships complicated (references in Dasgupta et al., 2017; Bose and Dasgupta, 2018).

A look at recent publications on EGB reveals that most of the authors adopt the classification of Dobmeier and Raith (2003), although the locations of the inter-province / domain boundaries are debated and their significance not clearly understood. The domain IB is rather poorly constrained with only a few isotopic data and the domain 4 (Angul) is similarly less investigated. Bulk of the petrological investigations have been undertaken in the EGP and Ongole Domain, although there remain significant differences in opinion on key metamorphic aspects (see next section of this article).

\section{Petrological evolution}

Given the fact that geochronological constraints on petrological events in the EGB point out major differences among the different domains or provinces, these are treated separately first in the following section. In case of all the areas, recent (collected over last 30 years) petrological data show consensus in terms of (a) peak P-T conditions, (b) time range of metamorphism, and (c) P-T path of metamorphism. Major discordance in opinion arise on two principal issues: (i) whether the EGB granulites are products of a single-cycle long-lived orogeny or multicycle shortduration orogenesis within one protracted period, and (ii) timing of amalgamation of the EGB with the cratonic blocks forming the Indian crustal architecture. It has, however, been established that UHT metamorphism occurred at different times in different domains / provinces. Besides, the exact configuration of the EGB in the context of Columbia, Rodinia and Gondwana is a focus of discussion, which is expected to continue as new data comes in. The source of anomalous amount of heat supply at the base of the crust has been speculated in the light of various tectonic models by different workers (Gupta, 2012; Dasgupta et al., 2013,2017; Mitchell et al., 2018; among others).

\section{The Domain 1A (Fig. 3)}

The rocks were affected by prominent ultrahigh temperature metamorphism at approximately 1.68-1.60 Ga at temperatures $.950 \mathrm{oC}$ and 6-7 kbar pressure along an anticlockwise P-T trajectory (Fig. 4a) (Simmat\&Raith 2008; Upadhyay et al. 2009; Bose et al. 2011; Henderson et al. 2014; Sarkar\& Schenk 2014). Sarkar\& Schenk (2014) and Sarkar et al. (2014) identified a separate distinct metamorphic phase at approximately $1.54 \mathrm{Ga}$ at higher pressures (9.5 kbar) and lower temperatures (7800C) followed by near-isothermal decompression to approximately 4 kbar (Fig. 4a).

Henderson et al. (2014), on the other hand, reported a similar spread of monazite and zircon ages, but preferred to interpret the scatter as being due to crystallization of zircon and monazite at different stages (prograde and retrograde) of a single metamorphic event. A switchover from compressional to extensional setting is indicated by the opening of an ocean basin and emplacement of alkaline rocks at approximately $1.45 \mathrm{Ga}$ (Upadhyay 2008), followed by brittle-ductile deformation at approximately $1.35 \mathrm{Ga}$ and a localized thermal overprint at approximately 1.10 Ga (Mezger\&Cosca 1999; Kovach et al. 2001; Simmat \& Raith 2008; Upadhyay et al. 2009). The Ongole Domain was, however, unaffected by the Grenvillian Orogeny that was so pervasive in the Eastern Ghats Province (see below). The tectonothermal events recorded in this Domain point to activities during the existence of Columbia supercontinent (see later).

\section{The Eastern Ghats Province}

\section{A. Isotopic domain 2 (Rickers et al., 2001) (Fig. 3)}

This is the most petrologically well-studied domain and shows sharply different evolutionary history with respect to Domain 1 . There are, however, serious disagreements on the nature of the P-T path of metamorphism, timing (s) of metamorphic events and their duration, and premetamorphic history of the rocks from this domain. Upadhyay et al. (2009) concluded, on the basis of detrital zircon populations, that sedimentation was probably induced at 1.40-1.20 Ga in the region with the opening of an ocean basin by rifting. On the other hand, Kelsey et al. (2017) obtained an emplacement age of $1.58 \mathrm{Ga}$ for mafic magma in this domain, which cannot be reconciled with the detrital zircon population. It remains to be verified whether the mafic rock dealt by Kelsey et al. (2017) forms the basement of the EGB, or not.

There is unanimity that the rocks have been subjected to an ultrahigh temperature $(\sim 1000 \mathrm{oC})$ at lower crustal depths 
(corresponding to 8-10 kbar pressure) along an anticlockwise P-T path at around $1 \mathrm{Ga}$ (reviewed in Dasgupta et al., 2017). Estimates of timing of this UHT metamorphism ranged from 1.03 Ga (Bose et al., 2011) to $1.13 \mathrm{Ga}$ (Korhonen et al., 2013)- a range within acceptable limits of uncertainty of the dating techniques. Mitchell et al. (2018), on the other hand, did not get an anticlockwise P-T path from an area within this domain, although they record similar UHT conditions at identical times. The retrograde P-T path of this UHT metamorphism is generally taken to be one of near-isobaric cooling, although there is no unanimity regarding the period of cooling (references in Dasgupta et al., 2017; Korhonen et al., 2013; Mitchell et al., 2018). While Bose et al. (2011) considered cooling up to $0.95 \mathrm{Ga}$, Korhonen et al (2013) and Mitchell et al. (2018) suggested cooling up to 0.9 Ga, implying that the UHT rocks resided at depth for a period exceeding $0.2 \mathrm{Ga}$. The essence of the contradiction lies in considering the domain 2 rocks to be products of a long-lived single cycle orogeny (Korhonen et al., 2013; Mitchell et al., 2018) or products of short-lived multiple orogenies within a protracted life of a hot orogen (Bose et al., 2011; Das et al., 2011). Bose et al. (2011) suggested a second tectonothermal event at 0.95-0.9 Ga with significant decompression during retrogression (reviewed in Dasgupta et al., 2013, 2017), a view shared by Kelsey et al. (2017). Mitchell et al. (2018) , on the other hand, disputed decompression during retrogression and did not comment on how the lower crustal granulites were exhumed and stated that the hot granulites resided in the middle crust up to $550 \mathrm{Ma}$.

The domain 2 granulites were re-worked during the Pan African orogeny at $\sim 500 \mathrm{Ma}$, under amphibolite facies conditions (reviewed in Dasgupta et al., 2017; Kelsey et al., 2017) or at higher temperatures ( 800 oC) (Mitchell et al., 2018). The importance of the Pan African remetamorphism of the Domain 2 granulites is being increasingly recognized in recent years. Summarizing, barring the issues related to single-cycle versus multi-cycle orogenesis and decompression during retrogression, broad consensus regarding the tectonothermal evolution of the Domain 2 has been arrived at through sustained efforts by several groups of workers.

Although there are disagreements on details, the broad evolutionary history of the Domain 2 bear striking similarity with the Rayner orogen in east Antarctica within the overall framework of the supercontinent Rodinia (Morissey et al., 2015; Dasgupta et al., 2017; Bose \& Dasgupta, 2018; Mitchell et al., 2018; Kelsey et al., 2017). The possible involvement of Domain 2 in East Gondwana will be discussed later.

\section{B. Isotopic Domain 3 (Rickers et al., 2001) (Figure 3)}

This domain contains rocks of the youngest protolith ages (1.80$2.20 \mathrm{Ga}$ ) in the EGB, and the northern and southern boundary of this domain corresponds to the Mahanadi and Nagavalli- Vamasdhara shear zones respectively (Fig. 2) (Rickers et al., 2001). There is an important difference in the lithological constitution of Domain 3, as compared to that of Domain 2, although these were clubbed together as Eastern Ghats Province by Dobmeier and Raith (2003). Although metapelitic migmatites, quartzofeldspathic gneisses,including charnockite, and minor calc-silicate and mafic granulites are common to both the domains, Domain 3 contains many more occurrences of massif-type anorthosite, which have been variously dated at approximately $0.79 \mathrm{Ga}$ (Krause et al. 2001),0.85 Ga (Chakrabarti et al. 2011) and $0.98 \mathrm{Ga}$ (Chatterjee et al. 2008). However, the anorthosite complexes have complex geological histories and there remains a possibility that zircon got reset. Most of the geochronological data constrains age of anorthosite magmatism between 0.93 -0.98 Ga. Recently, Ravikant (2019) dated the last amphibolites facies tectonothermal reworking of the anorthosite at $\sim 0.5 \mathrm{Ga}$.

Pelitic and calc-silicate rocks experienced UHT metamorphism ( 1000oC) at the contact of anorthosites (Raith et al., 2007; Sengupta et al., 2008), hence, the age of anorthosite magmatism needs to be constrained properly to assign an age of UHT metamorphism in this domain. A review of literature on metamorphic evolution of the rocks of this domain shows convergence in opinion about one phase of UHT metamorphism at 1 Ga (Raith et al., 2007; Simmat and Raith, 2008; Bose et al., 2016). Tectonothermal reworking of UHT granulites has been constrained within the time frame 0.8-0.5 Ga (Bose et al., 2016; Simmat and Raith, 2008). These later events are similar to those deduced by Mitchell et al.(2018) from the Domain 2. While the event at $0.8 \mathrm{Ga}$ coincides with the known time of disintegration of the supercontinent Rodinia, documentation of high grade (granulite facies) re-metamorphism at $\sim 0.5 \mathrm{Ga}$ in both the domains 2 and 3 (Mitchell et al., 2018;Bose et al., 2016 respectively) has important implications in the assembly of East Gondwana and correlation of parts of the EGB with east Antarctica.

Dobmeier and Raith (2003) considered a separate domain, named as Phulbani Domain, within the isotopic domain 3 of Rickers et al.(2001) (Figures 2 and 3 for comparison). The tectonometamorphic evolution of rocks from the Phulbani Domain resembles that of the isotopic domain 2 of Rickers et al. (2001) with a strong imprint of 0.98 Ga UHT metamorphism and a similar retrograde path (Ganguly et al., 2017).

\section{Isotopic Domain 4 (Angul Domain, Rickers et al., 2001) (Figure 3)}

Rather meager data is available regarding the metamorphic (and tectonic) evolution of rocks of this domain. Having protolith ages of 2.9-2.5 Ga (Rickers et al., 2001), an early granulite facies metamorphism at $\sim 1$ Ga was followed by an amphibolites facies overprint of uncertain age (0.5 Ga ?)(Sarkar et al., 2007).

\section{The Jeypore Province (Dobmeier and Raith, 2003) or Domain 1B (Rickers et al., 2001) (Figure 3)}

This geologically important province that could throw light on the nature and timing of craton (Bastar) - mobile belt (EGB) amalgamation received surprisingly low attention. There is hardly any petrological investigation in the Jeypore Province proper, particly on the dominant charnockitic rocks in the area. Ranjan et al. (2018) worked on alkaline rocks near Koraput, very near the Jeypore Province, and reported magmatism at $\sim 1.4 \mathrm{Ga}$ (breakdown of Columbia), $\sim 1 \mathrm{Ga}$ (assembly of Rodinia) and $\sim 0.8 \mathrm{Ga}$ (breakdown of Rodinia). This province coincides with the Transition Zone of Ramakrishnan et al.(1998), and is described to be a major shear zone, variously named by different workers with a well developed mylonitic zone (Gupta et al., 2000; Bhadra et al., 2004; Chatterjee et al., 2017).Neogi et al.(1999), Gupta et al.(2000) and Chatterjee et al.(2017) documented an UHT metamorphism with a isothermal decompression retrograde path from an area again close to the Jeypore Province (north of it). The age of UHT metamorphism can only be 
speculated as $\sim 0.5$ Ga based on limited isotopic data (Aftallion et al., 1998; Sarkar et al., 2000). Available information, therefore, does not support any similarity between the isotopic domains $1 \mathrm{~A}$ and $1 \mathrm{~B}$ of Rickers et al.(2001). Metamorphisms at 1 Ga, 0.7 Ga and 0.5 Ga have been recorded, and this aspect should be a focus of future study.

\section{The Rengali Province}

This province (Dobmeier and Raith,2003) is separated from the Domain 4 of the EGB by a strip of Gondwana sediments (Fig. 3), but lies at the contact of Singhbhum craton, and is, therefore, important to understand the EGB- Singhbhum amalgamation. Unfortunately, neither its relationship with the EGB proper nor with the Singhbhumcraton is understood clearly. Barring one sequence in the northern part of the Province, unambiguous record of $\sim 1 \mathrm{Ga}$ metamorphism has not been detected (Chattopadhyay et al., 2015). This single evidence is significant and may indicate the effect of the Grenvillian age orogeny of the EGB in this province. Otherwise, granulite facies metamorphism in this province is considered to be of Archean age ( 3.05-2.5 Ga, references in Dasgupta et al., 2017; Bose and Dasgupta, 2018). Structural and geochronological data further indicate that the Rengali Province evolved as a southern margin of the Singhbhum craton (Mahapatro et al., 2012, Bose et al., 2015, and others cited in Bose and Dasgupta, 2018). An alternative idea is that the northern boundary of the EGP with the Rengali Province is a strike-slip shear zone that possibly operated around 0.5 Ga (Misra and Gupta, 2014); the affinity of the Rengali Province could also be with the Bastar Craton. Sawant et al. (2017) pointed out structural, metamorphic and geochronologic similarities between the EGPRengali contact zone and the Rauer Group of East Antarctica, that also evolved as a c. 0.5 Ga strike-slip shear zone. It appears, therefore, that the ancestry of the Rengali Province as well as the nature and timing of tectonothermal events are poorly understood.

\section{Eastern Ghats Belt in the context of supercontinents}

Having summarized an updated status of the tectonothermal evolutionary history of the different isotopic and geological provinces / domains in the Eastern Ghats Belt, we now look briefly at the implications of these in the context of supercontinent assembly and dispersion. Numerous publications by different groups have addressed these issues and interested readers are referred to recent reviews (Dasgupta et al., 2013, 2017) for details. There is a general consensus that the crustal segment of the Eastern Ghats Belt that participated in the accretionary history Columbia was the Domain 1A. The collisional orogenesis at $1.54 \mathrm{Ga}$ was probably responsible for the amalgamation of the Napier Complex and the Dharwar craton with the Domain 1A to complete the Columbia formation. It is likely that the Domain 1A was cratonized at this time, since there is no evidence (so far) about subsequent major crustal re-working in this domain. There is only marginal evidence of the effect of the orogenesis related to the Grenvillian event, so prominent in other parts of the EGB.

Despite all the controversy related to the configuration of Rodinia and position of India within Rodinia (reviewed and referenced in Dasgupta et al., 2017; Bose and Dasgupta, 2018; Mitchell et al., 2018), it is commonly agreed that parts of the Eastern Ghats Province, particularly the isotopic domain 2 , formed a single orogen with the
Rayner Complex at $\sim 1 \mathrm{Ga}$ as a part of Enderbia or Rodinia. The pre1 Ga history has just started to unfold with the help of detrital zircon studies (Upadhyay, 2008; Mitchell et al., 2018). The source of sediments for the orogen could well be either the Indian or Antarctic side. While geological criteria strongly suggest an Indo-Antarctic correlation as a part of Rodinia, paleomagnetic data point otherwise. A critical appraisal of the different views is beyond the scope of the present contribution, and interested readers are referred to the literature cited above. The exact counterpart of the EGB in east Antarctica is a strongly debated topic, and many geological terranes have been mentioned in literature. Apparently, there are geological similarities between EGB and more than one terranesin east Antarctica. A final solution is clearly awaited. Another hotly debated topic is the reason behind the extremely hot orogen developed in the EGB at $\sim 1 \mathrm{Ga}$. Models predicting back arc tectonic setting to truncated hot orogen with contributions from high concentrations of HPE and slab breakoff / lithospheric delamination have been invoked to explain UHT metamorphism in the EGB (see reviews in Dasgupta et al., 2017; Mitchell et al., 2018; references therein). The discordance in opinion regarding existence of a long-lived hot orogen or of a hot orogen with short-lived repeated orogenesis has already been referred to. These are important areas for future research not only with respect to EGB, but also in models of tectonism and metamorphism in general.

The tectonothermal event at $0.78-0.8 \mathrm{Ga}$ in the domain 3 has been interpreted as an outcome of breakdown of Rodinia, implying thereafter a separation between domain 2 and domain 3-4. An alternate view does not invoke separation, but continuation as a single block as a part of a longlived hot orogen. There is, however, a convergence of opinion that the $\sim 0.5 \mathrm{Ga}$ event in domains 2 and 3 are related to the development of the Prydz Bay orogen in east Antarctica. This attests the notion of Harley (2003) that EGB was connected to Prydz Bay region as a part of East Gondwana. The exact significance of the effects of Pan African orogeny in the EGB needs to be worked out.

Notwithstanding all the controversies, it is evident from the above that the EGB played a dominant role in the configurations of Columbia, Rodinia and East Gondwana, and is certainly worthy of the geological importance it has received.

\section{Outstanding Issues and concluding remarks}

As stated earlier, this article was not intended to be a critical appraisal of the different debated issues related to the Eastern Ghats Belt, but to present a collation of published data and to flag outstanding issues. I shall highlight some of these major outstanding issues in this section about which controversies have already been mentioned in the preceding sections.

(a) The entire EGB experienced at least one phase of UHT metamorphism at mid- lower crustal depths, but at different times in various Provinces/ Domains. Apart from the question of resolving the cause of UHT metamorphism, one wonders whether tectonic settings were similar or different, and, if same, why were these repeated.

(b) Was the UHT metamorphic pulse a single long-lived protracted one, or a multicycle one with distinct time gaps ?

(c) While it is understood that identification of possible counterparts of the EGB in east Antarctica will be speculative, 
detail petrological, isotopic and structural investigations are required along the contacts of EGB with the three cratonic blocks to ascertain whether the cratonization of EGB was completed by $\sim 1 \mathrm{Ga}$ or at $\sim 0.5 \mathrm{Ga}$ to define the present crustal architecture of India.

(d) Identification, characterization and implications of the different geologic / isotopic Provinces and Domains within the EGB and nature of the boundaries in between are not clearly understood, and often contradictory. Extensive in-situ high-precision geochronological data from multiple minerals or domains therein linked with the petrological histories of the rocks can resolve the outstanding issues. A related unsolved issue is the timing and mechanism of amalgamation of different isotopic / lithotectonic domains / provinces.

(e) Certainly lack of petrological information on the Jeypore Province is a hindrance to understand its relation with the isotopic domain 2 and the contact relation with the Bastar craton.

(f) The status of the Rengali Province with respect to the Bastar and Singhbhum cratons needs to be investigated.

(g) More information (detrital zircon data) is required to fix timing of opening of ocean basin(s) and source of detritus.

(h) Not much work has been done on the nature of the basement of the EGB, which would require extensive isotopic data, particularly Hf isotopes.

\section{Acknowledgment}

I thank Saibal Gupta for inviting me to write this article. Comments by Dr. D. Upadhyay improved the article. Discussions with Pulak Sengupta, Santanu Bhowmik, Sankar Bose, Masato Fukuoka, Michael Raith and numerous students and co-workers over the last four decades were very helpful.

\section{References}

Bhadra, S., Gupta, S. and Banerjee, M., 2004, Structural evolution across the Eastern Ghats Mobile Belt-Bastar craton boundary, India: hot over cold thrusting in an ancient collision zone. Journal of Structural Geology, v. 26, pp. 233-245.

Bhowmik, S.K., Dasgupta, S., Hoernes, S. , and Bhattacharya, P.K., 1995, Extremely hightemperature calcareous granulites from the Eastern Ghats, India: evidence for isobaric cooling, fluid buffering and terminal channelized fluid flow. European Journal of Mineralogy, v. 7, pp. 689-703.

Bose, S., Fukuoka, M., Sengupta, P., and Dasgupta, S., 2000, Evolution of high $\mathrm{Mg}-\mathrm{Al}$ granulites from Sunkarametta, Eastern Ghats, India: evidence for a lower crustal heating- cooling trajectory. Journal of Metamorphic Geology, v. 18, pp. 223-240.

Bose, S., Dunkley, D.J., Dasgupta, S., Das, K., and Arima, M., 2011, India-Antarctica- Australia-Laurentia connection in the PaleoMesoproterozoic revisited: evidence from new zircon $\mathrm{U}-\mathrm{Pb}$ and monazite chemical age data from the Eastern Ghats Belt, India. Geological Society of America Bulletin, v. 123, pp. 2031-2049.

Bose, S., Guha, S., Ghosh, G., Das, K., and Mukhopadhyay, J., 2015, Tectonic juxtaposition of crust and continental growth during orogenesis: example from the Rengali Province, eastern India. Geoscience Frontiers, v. 6, pp. 537-555.

Bose, S., Das, K., Kimura, K., Hidaka, H., Dasgupta, A., Ghosh, G., and Mukhopadhyay, J., 2016a, Neoarchean tectonothermal imprints in the Rengali Province, eastern India and their implication on the growth of Singhbhum Craton: evidence from zircon U-Pb SHRIMP data. Journal of Metamorphic Geology, v. 34, pp. 743-764.

Bose, S., Das, K., Torimoto, J., Arima, M., and Dunkley, D.J., 2016b, Evolution of the Chilka Lake granulite complex, northern Eastern Ghats Belt, India: first evidence of c. 780 Ma decompression of the deep crust and its implication on the India-Antarctica correlation. Lithos, v. 263, pp. 161-189.

Brown, M., 2006. Duality of thermal regimes is the distinctive characteristic of plate tectonics since the Neoarchean. Geology, v. 34, pp. 961-964.

Chakrabarti, R., Basu, A.R., Bandyopadhyay, P.K., and Zou, H., 2011, Age and origin of the Chilka anorthosites, Eastern Ghats, India: implications for massif anorthosite petrogenesis and break-up of Rodinia. In: Ray, J., Sen, G., and Ghosh, B. (Eds.), Topics in Igneous Petrology. Springer, Berlin, pp. 355-382.

Chatterjee, N., Crowley, J.L., Mukherjee, A., and Das, S., 2008, Geochronology of the 983-Ma Chilka Lake anorthosite, Eastern Ghats Belt India: implications for Pre-Gondwana tectonics. Journal of Geology, v. 116, pp. 105-118.

Chattopadhyay, S., Upadhyay, D., Nanda, J.K., Mezger, K., Pruseth, K.L., and Berndt., J., 2015, Proto-India was a part of Rodinia: evidence from Grenville-age suturing of the Eastern Ghats Province with the Paleoarchean Singhbhum Craton. Precambrian Research, v. 266, pp. 506-529.

Chetty, T.R.K., and Murthy, D.S.N., 1998, Regional tectonic framework of the Eastern Ghats Mobile Belt: a new interpretation. Geological Survey of India Special Publication, v. 44, pp. 39-50. Crowe, W.A., Cosca, M.A., and Harris, L.B., 2001, 40Ar/39Ar geochronology and Neoproterozoic tectonics along the northern margin of the Eastern Ghats Belt, in north Orissa, India. Precambrian Research, v. 108, pp. 237-266.

Crowe, W.A., Nash, C.R., Harris, L.B., Leeming, P.M., and Rankin, L.R., 2003,The geology of the Rengali Province: implications for the tectonic development of northern Orissa, India. Journal of Asian Earth Science, v. 21, pp. 697-710.

Das, K., Bose, S., Karmakar, S., Dunkley, D.J., and Dasgupta, S., 2011, Multiple tectonometamorphic imprints in the lower crust: first evidence of c. 950 Ma compressional reworking of older UHT metamorphosed aluminous granulites from the Eastern Ghats Belt, India. Geological Journal, v. 46, pp. 217-239.

Dasgupta, S., 1993, Contrasting mineral parageneses in hightemperature calc-silicate granulites: examples from the Eastern Ghats, India. Journal of Metamorphic Geology, v. 11, pp. 193202.

Dasgupta, S., and Sengupta, P., 2003. Indo-Antarctic correlation: a perspective from the Eastern Ghats Granulite Belt, India. I n: Yoshida, M., Windley, B.F., and Dasgupta, S. (Eds.) Proterozoic East Gondwana: Supercontinent Assembly and Breakup. Geological Society, London, Special Publications, v. 206, pp. 131143,

Dasgupta, S., Sengupta, P., Ehl, J., Raith, M., and Bardhan, S., 1995, Reaction textures in a suite of spinel granulites from Eastern Ghats Belt, India: evidence for polymetamorphism and a partial petrogenetic grid in the system KFMASH and the roles of $\mathrm{ZnO}$ and Fe2O3. Journal of Petrology, v. 36, pp. 435-461.

Dasgupta, S., Bose, S., and Das, K., 2013. Tectonic evolution of the Eastern Ghats Belt. Precambrian Research, v. 227,pp. 247-258.

Dasgupta, S., Bose, S., Bhowmik, S.K., and Sengupta, P., 2017, The Eastern Ghats Belt, India, in thecontext of supercontinent assembly, In: Dasgupta, S., and Pant, N.C. (Eds.), Crustal Evolution of India and Antarctica: The Supercontinent Connection, Geological Society of London Special Publication, v. 457, pp. 87-104. 
Dharma Rao, C.V., Santosh, M., and Chmielowski, R., 2012a. Sapphirine granulites from Panasapattu, Eastern Ghats belt, India: ultrahigh-temperature metamorphism in a Proterozoic convergent plate margin. Geoscience Frontiers, v. 3, pp. 9-31.

Dobmeier, C.J., and Raith, M.M., 2003. Crustal architecture and evolution of the Eastern Ghats Belt and adjacent regions of India. In: Yoshida, M., Windley, B.F., and Dasgupta, S. (Eds.) Proterozoic East Gondwana: Supercontinent Assembly and Breakup. Geological Society, London, Special Publications, v. 206, pp. 145-168.

Ganguly, P., Bose, S., Das, K., Torimoto, J., and Ghosh, G., 2017, Origin of spinel+quartz assemblage in a Si-undersaturated ultrahigh temperature aluminous granulite and its implication for the P-T-fluid history of the Phulbani domain, Eastern Ghats Belt, India. Journal of Petrology, v. 58, pp. 1941-1974.

Ghosh, G., Bose, S. et al.,2016, Transpression and juxtaposition of middle crust over upper crust forming a crustal scale flower structure: insight from structural, fabric, and kinematic studies from the Rengali Province, eastern India. Journal of Structural Geology, v. 83, pp. 156-179.

Grew, E.S., and Manton, W.I., 1986, A new correlation of sapphirinegranulites in the Indo- Antarctic metamorphic terrane: late Proterozoic dates from the Eastern Ghats. Precambrian Research, v. 33, pp. 123-139.

Gupta, S., Bhattacharya, A., Raith, M., and Nanda, J.K., 2000, Pressure - temperature - deformational history across a vestigial craton -mobile belt boundary: the western margin of the Eastern Ghats Belt at Deobhog, India. Journal of Metamorphic Geology, v. 18, pp. 683-697.

Gupta, S., 2012. Strain localization, granulite formation and geodynamic setting of 'hot orogens': a case study from the Eastern Ghats Province, India. Geological Journal, v. 47, pp. 334-351.

Harley, S.L., 2003, Archaean-Cambrian development of East Antarctica: metamorphic characteristics and tectonic implications. In: Yoshida, M., Windley, B.F., and Dasgupta, S. (Eds.) Proterozoic East Gondwana: Supercontinent Assembly and Breakup. Geological Society, London, Special Publications, v. 206, pp. 203-230.

Harley, S.L., 2008, Refining the P-T records of UHT crustal metamorphism. Journal of Metamorphic Geology, v. 26, pp. 125-154.

Henderson, B., Collins, A.S., Payne, J., Forbes, C., and Saha, D., 2014, Geologically constraining India in Columbia: the age, isotopic provenance and geochemistry of the protoliths of the Ongole Domain, Southern Eastern Ghats, India. Gondwana Research, v. 26, pp. 888-906.

Kamineni, D.C., and Rao, A.T., 1988, Sapphirine-bearing quartzite from the Eastern Ghats granulite terrain, Vizianagaram, India. The Journal of Geology, v. 96(2), pp. 209-220.

Kelsey, D.E., 2008, On ultrahigh-temperature crustal metamorphism. Gondwana Research, v. 13, pp. 1-29.

Kelsey, D. E., Morrissey, L. J., Hand, M., Clark, C., Tamblyn, R., Gaehl, A. A., and Marshall, S., 2017, Significance of post peak metamorphic reaction microstructures in the ultrahigh temperature Eastern Ghats Province, India. Journal of Metamorphic Geology, v. 35( 9), pp. 1081- 1109.

Korhonen, F.J., Clarke, C., Brown, M., Bhattacharya, S., Taylor, R.,2013, How long-lived is ultrahigh temperature (UHT) metamorphism? Constraints from zircon and monazite geochronology in the Eastern Ghats orogenic belt, India. Precambrian Research, v. 234, pp. 322- 350.

Kovach, V.P., Simmat, R. et al., 2001, The Western Charnockite Zone of the Eastern Ghats Belt, India- an independent crustal province of late Archaean (2.8 Ga) and Palaeoproterozoic (1.7-1.6 Ga) terrains. Gondwana Research, v. 4, pp. 666-667.
Krause, O., Dobmeier, C., Raith, M.M., and Mezger, K., 2001, Age of emplacement of massiftype anorthosites in the Eastern Ghats Belt, India: constraints from U-Pb zircon dating and structural studies. Precambrian Research, v. 109(1-2), pp. 25-38.

Lal, R.K., Ackermand, D., and Upadhyay, H., 1987, P-T-X relationships deduced from corona textures in sapphirine-spinelquartz assemblages from Paderu, southern India. Journal of Petrology, v. 28, pp. 1139-1168.

Li, Z.X., Bogdanova, S.V. et al., 2008, Assembly, configuration, and break-up history of Rodinia: a synthesis. Precambrian Research, v. 160, pp. 179-210.

Mahapatro, S.N., Pant, N.C., Bhowmik, S.K., Tripathy, A.K., and Nanda, J. K., 2012, Archaean granulite facies metamorphism at the Singhbhum craton-Eastern Ghats Mobile Belt interface: implication for the Ur supercontinent assembly. Geological Journal, v. 47, pp. 312-333.

Mezger, K., and Cosca, M.A., 1999. The thermal history of the Eastern Ghats Belt (India), as revealed by U-Pb and 40Ar-39Ar dating of metamorphic and magmatic minerals: implications for the SWEAT correlation. Precambrian Research, 94, 251-271.

Misra, S. and Gupta, S., 2014, Superposed deformation and inherited structures in an ancient dilational step-over zone: post-mortem of the Rengali Province, India. Journal of Structural Geology, v. 59, pp. 1-17.

Mitchell, R. J., Johnson, T. E., Clark, C., Gupta, S., Brown, M., Harley, S.L., and Taylor, R., 2018, Neoproterozoic evolution and Cambrian reworking of ultrahigh temperature granulites in the Eastern Ghats Province, India. Journal of Metamorphic Geology, v. 00, pp. 1-30, https://doi.org/ 10.1111/jmg.12451.

Morrissey, L.J., Hand, M., Kelsey, D.E., 2015, Multistage metamorphism in the Rayner-Eastern Ghats terrane: $\mathrm{P}-\mathrm{T}-\mathrm{t}$ constraints from the northern Prince Charles Mountains, east Antarctica. Precambrian Research, v. 267, pp. 137-163.

Nanda, J., and Gupta, S., 2012, Intracontinental orogenesis in an ancient continent-continent collision zone: evidence from structure, metamorphism, and PT paths across a suspected suture zone within Eastern Ghats Belt, India. Journal of Asian Earth Sciences, v. 49, pp. 376- 395.

Nanda, J., Gupta, S., and Hacker, B., 2018, U-Pb zircon and titanite ages from granulites of the Koraput area-evidence for Columbia, Rodinia and Gondwana from the Eastern Ghats Province, India. Precambrian Research, v. 314, pp. 394-413.

Paul, D.K., Raybarman, T.K., McNaughton, N.J., Fletcher, I.R., Potts, P.J., Ramakrishnan, M., and Augustine, P.F., 1990, ArcheanProterozoic evolution of Indian charnockites: isotopic and geochemical evidence from granulites of the Eastern Ghats Belt. The Journal of Geology, v. 98(2), pp. 253-263.

Raith, M. M., Dobmeier, C., and Mouri, H., 2007, Origin and evolution of $\mathrm{Fe}-\mathrm{Al}$ granulites in the thermal aureole of the Chilka Lake anorthosite, Eastern Ghats Province, India. Proceedings of Geological Association, v. 118, pp. 87-100.

Ramakrishnan, M., Nanda, J.K., and Augustine, P.F., 1998, Geological evolution of the Proterozoic Eastern Ghats mobile belt. Geological Survey of India Special Publication, v. 44, pp. 1-21.

Ranjan, S., Upadhyay, D., Abhinay, K., Pruseth, K.L., and Nanda, J. K., 2018, Zircon geochronology of deformed alkaline rocks along the Eastern Ghats Belt margin: India-Antarctica connection and the Enderbia continent. Precambrian Research, doi: https:// doi.org/10.1016/j.precamres.2018.04.005.

Ravikant, V., 2019, Cambrian Garnet Sm-Nd Isotopic Ages from the Polydeformed Bolangir Anorthosite Complex, Eastern Ghats Belt, India: Implications for Intraplate Orogeny Coeval with Kuunga Orogeny during Gondwana Assembly. Journal of Geology, v. 127, 437- 456. 
Rickers, K., Mezger, K., and Raith, M.M., 2001, Evolution of the continental crust in the Proterozoic Eastern Ghats Belt, and new constraints for Rodinia reconstruction: implications from Sm$\mathrm{Nd}, \mathrm{Rb}-\mathrm{Sr}$ and $\mathrm{Pb}-\mathrm{Pb}$ isotopes. Precambrian Research, v. 112, pp. 183-212.

Rogers, J.J.W., 1996, A history of continents in the past three billion years. The Journal of Geology, v. 104(1), pp. 91-107.

Rogers, J.J., and Santosh, M., 2002, Configuration of Columbia, a Mesoproterozoic supercontinent. Gondwana Research, v. 5, pp. 5-22.

Sarkar, M., Gupta, S., and Panigrahi, M.K., 2007, Disentangling tectonic cycles along a multiply deformed terrane margin: structural and metamorphic evidence for mid-crustal reworking of the Angul granulite complex, Eastern Ghats Belt, India. Journal of Structural Geology, v. 29, pp. 802-818.

Sarkar, T., and Schenk, V., 2014, Two-stage granulite formation in a Proterozoic magmatic arc (Ongole domain of the Eastern Ghats Belt, India): Part 1. Petrology and pressuretemperature evolution. Precambrian Research, v. 255, pp. 485-509.

Sarkar, T., Schenk, V., Appel, P., Berndt, J., and Sengupta, P., 2014, Two-stage granulite formation in a Proterozoic magmatic arc (Ongole domain of the Eastern Ghats Belt, India): part 2. LAICP-MS zircon dating and texturally controlled in situ monazite dating. Precambrian Research, v. 255, pp. 467-484.

Sarkar, T., Schenk, V., and Berndt, J., 2015, Formation and evolution of a Proterozoic magmatic arc: geochemical and geochronological constraints from metaigneous rocks of the Ongole domain, Eastern Ghats Belt, India. Contributions to Mineralogy and Petrology, v. 169, DOI 10.1007/s00410-014-1096-1.

Sawant, A. D., Gupta, S., Clark, C., and Misra, S., 2017, The RauerRengali connection in the Indo- Antarctica amalgam: evidence from structure, metamorphism and geochronology. From: Pant, N. C., Dasgupta, S. (Eds.) Crustal Evolution of India and
Antarctica: The Supercontinent Connection. Geological Society, London, Special Publications, v. 457, pp. 171-196.

Sengupta, P., Dasgupta, S., Bhattacharya, P.K., Fukuoka, M., Chakraborti, S., and Bhowmik, S., 1990, Petro-tectonic imprints in the sapphirinegranulites from Anantagiri, Eastern Ghats Mobile Belt, India. Journal of Petrology, v. 31, pp. 971-996.

Sengupta, P., Sen, J., Dasgupta, S., Raith, M.M., Bhui, U.K., and Ehl, J., 1999, Ultrahigh temperature metamorphism of metapeliticgranulites from Kondapalle, Eastern Ghats Belt: implications for the Indo-Antarctic correlation. Journal of Petrology, v. 40, pp. 1065-1087.

Sengupta, P., Dasgupta, S., Dutta, N., and Raith, M.M., 2008, Petrology across a calc-silicate- anorthosite interface from the Chilka Lake Complex, Orissa: implications for Neoproterozoic crustal evolution of the Eastern Ghats Belt. Precambrian Research, v. 162 , pp. $40-58$.

Simmat,R., and Raith, M.M., 2008, U-Th-Pb monazite geochronometry of the Eastern GhatsBelt, India: timing and spatial disposition of poly-metamorphism. Precambrian Research, v. 162, pp. 16-39.

Upadhyay, D., 2008, Alkaline magmatism along the southeastern margin of the Indian shield: implications for regional geodynamics and constraints on craton-Eastern Ghats Belt suturing. Precambrian Research, v. 162, pp. 59-69.

Upadhyay, D., Gerdes, A., and Raith, M.M., 2009, Unraveling sedimentary provenance and tectonothermal history of high to ultra-high temperature metapelites using zircon and monazite chemistry: a case study from the Eastern Ghats Belt, India. Journal of Geology, v. 117, pp. 665- 683.

Zhao, G., Sun, M., Wilde, S.A., and Li, S., 2004, A PaleoMesoproterozoic supercontinent: assembly, growth and breakup. Earth-Science Reviews, v. 67, pp. 91-123.

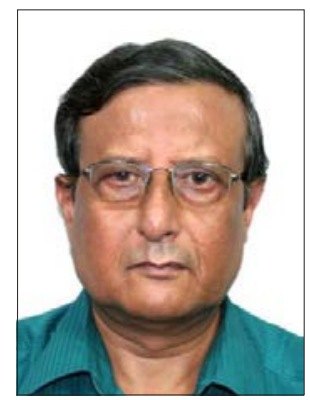

Somnath Dasgupta has been working on the Eastern Ghats Belt for over three decades along with students and collaborators. He is a former Professor of Jadavpur University and IISER-Kolkata, and is a Fellow of all the three science academies of India, TWAS, and Alexander von Humboldt Foundation and a former Mercator Guest Professor at Ruhr University, Bochum and a Visiting Professor at Hokkaido University. Currently, he is a Visiting Professor at IISER -Kolkata. 